\title{
Pengaturan Sertifikasi Jaminan Produk Halal Di Indonesia
}

\author{
Mutiara Fajrin Maulidya Mohammad \\ Fakultas Hukum, Universitas Airlangga, Surabaya-Indonesia \\ mutiarafajrin3@gmail.com
}

Published: 25/07/2021

How To Cite:

Mohammad, M. F. M. (2021). Pengaturan Sertifikasi Jaminan Produk Halal Di Indonesia. KERTHA WICAKSANA: Sarana Komunikasi Dosen dan Mahasiswa. 15(2). Pp 149-157. https://doi.org/10.22225/kw.15.2.2021.149157

\begin{abstract}
Abstrak
Aturan yuridis tentang Jaminan Produk Halal di Indonesia adalah hal yang krusial, wajar sebab penduduk Indonesia mayoritas beragama islam, wajib bagi negara untuk menjamin hak-hak konsumen muslimnya. Dengan adanya Undang-Undang Nomor 33 Tahun 2014 Tentang JPH, yang mengatur bagaimana hak dan kewajiban para pelaku usaha kaitannya dengan produksi produk-produk halal, diharapkan dapat memberikan kepastian dan jaminan hukum bagi konsumen muslim. Diperkuat dengan terbitnya Peraturan Pemerintah Nomor 31 Tahun 2019 dan diikuti dengan dikeluarkannya Peraturan Menteri Agama Nomor 26 Tahun 2019 Tentang Penyelenggara JPH. Tulisan ini bermaksud untuk mendeskripsikan lembaga-lembaga pelaksana, mekanisme dan pemberlakuan sertifikasi halal di Indonesia. Metode yang digunakan ialah statute approach/pendekatan Undang-Undang, dilakukan dengan menelaah semua perundang-undangan yang bersangkut paut dengan isu hukum yang sedang terjadi. Hasilnya ialah dengan adanya PP tersebut, semakin memperjelas bahwa betapa mendesaknya permasalahan halal dan haram di Indonesia. Menunjuk bahwa terdapat tiga lembaga urgent yang berwewenang menjalankan sertifikasi halal diIndonesia, yakni ada BPJPH, LPH, dan MUI. BPJPH mempunyai kewenangan untuk bekerjasama salah satunya dengan Kementerian dan/atau lembaga terkait, bentuk kerjasamanya harus sesuai dengan tugas dan fungsi tiap-tiap kementerian. Sedangkan untuk prosedur pengajuan sertifikasi halal dilaksanakan melalui enam tahapan, yakni: mulai dari pengajuan permohonan, pemeriksaan kelengkapan, penetapan LPH, pemeriksaan/pengujian oleh auditor, penetapan kehalalan oleh MUI dan terakhir penerbitan sertifikasi halal. Kewajiban sertifikasi halal sesuai dengan UUJPH diberlakukan mulai pada tanggal 17 Oktober 2019 sampai dengan tanggal 17 Oktober 2024. Pelaksanaannya dilakukan secara bertahap dengan mempertimbangkan kesiapan pelaku usaha, infrastruktur pelaksanaan JPH, mempertimbangkan jenis Produk sebagai kebutuhan primer dan dikonsumsi secara masif.
\end{abstract}

Kata Kunci: Lembaga; Mekanisme; Pelaksanaan; JPH.

\begin{abstract}
The Law about the Guarantee of Halal Products in Indonesia are crucial, it is normal because Indonesian residents who are Muslim, the state are obliged to guarantee the rights of Muslim consumers. The existence of Law No. 33/ 2014 About JPH, which guides the rights and obligations of business actors with halal products, is expected to provide legal certainty and guarantee for Muslim consumers. Strengthened by the issuance of Government Regulation No.31/ 2019 followed by the issuance of Regulation of the Minister of Religion Number 26/2019 About JPH Administrators. This paper was published to describe the implementing agencies and enforcement of halal certification in Indonesia. The method utilized in this paper is the statutory approach, which is carried out by reviewing all laws that are related to the current legal problem. The result is the existence of PP No.31/2019, it is increasingly clear that the closeness of the halal and haram issues in Indonesia. It shows that there are three institutions urgent they have the authority to carry out halal certification in Indonesia, namely BPJPH, LPH, and MUI. BPJPH has the authority to among others, with the Ministries, the form of cooperation must be in accordance with the duties and functions of each ministry. Meanwhile, the procedure for submitting certification is carried out in six stages, starting from submitting an application, completing inspection, determining the LPH, examining/testing by a halal auditor, determining halalness by MUI and finally get a halal certification. The obligation for halal certification in accordance with UUJPH is enforced from 17 October 2019
\end{abstract}


to 17 October 2024. The implementation is carried out in stages by taking into account the readiness of business actors, the infrastructure for implementing JPH, considering the type of product as primary needs and being used massively.

Keywords: Institutions; Mechanisms; Implementation; JPH

\section{PENDAHULUAN}

Persentase muslim Indonesia mencapai 23,2\% dari populasi muslim dunia, dari 209 juta penduduk Indonesia, setidaknya $87,2 \%$ beragama Islam (Kusnandar, 2019). Mengacu kepada Badan Pusat Statistik pada tahun 2010, Indonesia dihuni oleh sedikitnya penduduk yang beragama Kristen sebanyak (6,96\%), Katolik (2,91\%), Hindu $(1,69 \%)$, Budha $(0,72 \%)$ dan sisanya menganut agama yang lain (Statistik, 2010). Hal tersebut mengindikasikan bahwa Indonesia merupakan negara dengan mayoritas penduduk beragama islam.

Sesuai dengan keyakinan agama, seorang muslim diwajibkan untuk mengkonsumsi produkproduk yang halal dan toyyib saja. Terlebih karena status kehalalan suatu produk merupakan masalah sensitif, berkaitan langsung dengan akidah atau kehidupan spiritual muslim (Endah, 2014). Konsep halal sendiri mengacu pada boleh tidaknya produk tersebut dipergunakan berdasar al-quran dan as-sunnah, sedangkan konsep toyyib artinya bagus, ia lebih mengutamkan pada kualitas produk, kandungan gizi, kebersihan, keamanan, dan kesehatan (Hasan, 2014). Konsumen muslim tidak hanya membutuhkan produk-produk yang aman dan bermutu saja tetapi juga membutuhkan produk-poduk yang bersertifikasi halal.

Berawal dari permasalahan yang terjadi pada tahun 1988, Prof.Dr.Tri Susanto, M.App.Sc, seorang profesor dari Universitas Brawijaya menemukan produk-produk turunan dari babi, seperti gelatin maupun lemak babi dalam makanan dan minuman yang beredar dipasaran. Hal tersebut menjadi masalah nasional, isu tersebut mengakibatkan penjualan produk mengalami penurunan sebesar $20 \%$ sampai $30 \%$. Lalu kasus beredarnya daging celeng dipasaran pada tahun 2000-2002, kasus Ajinomoto pada tahun 2001, dan kasus vaksin meningitis jemaah haji yang mengandung enzim babi pada tahun 2009. Untuk memecahkan masalah tersebut Majelis Ulama Indonesia (MUI) mendirikan lembaga untuk studi tentang makanan dan obatobatan yang dikenal dengan sebutan LPPOMMUI (A.S, 1999). LPOM-MUI dibentuk untuk meredam kepanikan dan mengembalikan kepercayaan masyarakat. Saat itu pendaftaran sertifikasi halal untuk para pengusaha masih bersifat sukarrela.

Tidak cukup disitu, untuk mengatasi kekuatiran konsumen akan produk halal, lalu memberikan pelindungan dan penjaminan tentang kehalalan Produk yang dikonsumsi dan dipakai oleh masyarakat, negara mengesahkan UndangUndang Nomor 33 Tahun 2014 Tentang Jaminan Produk Halal, tepatnya pada tanggal 17 Oktober 2014, tujuannya ialah untuk memberikan kepastian status kehalalan, sehingga dapat menenteramkan batin (hati) konsumen dalam mengkonsumsinya. Sertifikasi halal sendiri adalah suatu proses untuk memperoleh sertifikat halal melalui beberapa tahap untuk membuktikan bahwa bahan, proses produksi dan sistem jaminan halal memenuhi standar Lembaga Pengkajian dan Pensertifikasian Halal di Indonesia. Hasilnya produk para pelaku usaha diberi label kehalalan, yang saat ini Label halal dianggap sebagai simbol atas kualitas, kesehatan, kebersihan, dan praktik etika.

Undang-Undang Nomor 33 Tahun 2014 memiliki pokok pengaturan, Pertama, untuk menjamin ketersediaan Produk Halal yang mencakup penyediaan bahan, pengolahan, penyimpanan, pengemasan, pendistribusian, penjualan, dan penyajian Produk. Kedua, mengatur hak dan kewajiban pelaku usaha dengan memberikan pengecualian terhadap Pelaku Usaha yang memproduksi Produk dari Bahan yang berasal dari Bahan yang diharamkan. Ketiga, bentuk tanggung jawab pemerintah dalam penyelenggaraan jaminan produk halal yang pelaksanaannya dilakukan oleh BPJPH (didirikan pada tanggal 11 Oktober 2017). Terhitung 2019 sertifikasi halal dipegang oleh Kementerian Agama, tidak lagi menjadi kewenangan MUI secara mutlak. MUI tetap dilibatkan dalam penerbitan sertifikasi halal ini. MUI sebagai auditor terhadap produk yang didaftarkan. Dalam menjalankan wewenangnya, BPJH bekerja sama dengan kementerian dan/atau lembaga terkait, MUI, dan LPH. Keempat, Tata cara memperoleh Sertifikat Halal beserta biayanya. Kelima, bentuk pengawasan. Dan yang terakhir, mengatur tentang penegakan hukum terhadap pelanggaran Undang- 
Undang ini, ditetapkan sanksi administratif dan sanksi pidana.

Berkaitan dengan itu dalam realitasnya banyak Produk yang beredar di masyarakat belum semua terjamin kehalalannya, masyarakat masih merasa kesulitan untuk membedakan mana produk yang halal dan mana produk yang haram bagi yang beragama muslim (Ilyas, 2017). Sehingga lima tahun kemudian, tepatnya bulan April 2019 Peraturan Pemerintah Nomor 31 Tahun 2019 Tentang Peraturan Pelaksana Undang-undang Nomor 33 Tahun 2014 Tentang Jaminan Produk Halal disahkan, diikuti dengan dikeluarkannya Peraturan Menteri Agama Nomor 26 Tahun 2019 Tentang Penyelenggara Jaminan Produk Halal. Dengan dikeluarkannya peraturan pelaksana maka mulai 17 Oktober, sesuai dengan amanat pasal 4 UUJPH maka produk yang masuk, beredar, dan diperdagangkan di wilayah Indonesia wajib bersertifikat halal.

Lahirnya Peraturan Pemerintah Nomor 31 Tahun 2019 sesungguhnya semakin mempertegas betapa mendesaknya persoalan halal-haram dalam rantai produksi dari pelaku usaha hingga sampai di tangan konsumen dan dikonsumsi oleh konsumen. Pemberlakuan peraturan pemerintah bertujuan agar pihak konsumen (masyarakat luas) mendapatkan kepastian hukum terhadap produk makanan dan barang konsumsi lainnya. Sedangkan bagi pelaku usaha, hadirnya peraturan pemerintah memberikan panduan yang lebih terang bagaimana mengolah, memproses, memproduksi, dan memasarkan produk kepada masyarakat konsumen, serta bagaimana membuat informasi produk halal kepada konsumen (RFQ, 2014).

Berdasarkan latar belakang masalah tersebut penelitian ini berfokus pada bagaimana jalannya pelaksanaan Undang-Undang Nomor 33 Tahun 2014 setelah adanya Peraturan Pelaksana, yakni bagaimana pengaturan tentang jaminan produk halal di Indonesia dan apakah dengan dikeluarkannya peraturan perlaksana akan memperterang jalannya pelaksanaan dari UndangUndang Nomor 33 Tahun 2014.

Berdasarkan hal tersebut pula tulisan ini lebih spesifik bermaksud untuk mendeskripsikan. Pertama, siapa lembaga-lembaga yang berwenang dalam melaksanakan jaminan produk halal di Indonesia. Kedua, bagimana mekanisme pengajuan dan perpanjangan sertifikasi halal. Dan ketiga, kapan kewajiban pemberlakuan sertifikasi halal di Indonesia dilaksanakan.

\section{METODE}

Jenis metode penelitian yang dilakukan dalam penulisan ini adalah metode penelitian hukum normatif atau disebut pendekatan perundangundangan (statute approach), dilakukan dengan menelaah semua undang-undang dan regulasi yang bersangkut paut dengan isu hukum yang sedang dijalani. Dalam penelitian ini akan dibahas, antara lain, Undang-Undang beserta Peraturan Pelaksana dibawahnya (Marzuki, 2001).

Pendekatan perundang-undangan ini dilakukan dengan cara mempelajari ratio legis dan dasar ontologis suatu undang-undang dan menangkap kandungan filosofi dengan tujuan dapat menyimpulkan mengenai ada tidaknya kaitan filosofis antara undang-undang dengan isu hukum yang dihadapi (Marzuki, 2016). Pendekatan ini dilakukan untuk mengetahui filosofi diaturnya jaminan produk halal di Indonesia.

Sumber bahan hukum yang digunakan dalam penelitian ini berupa bahan hukum primer dan bahan hukum sekunder. Bahan hukum primernya adalah (1) Undang-Undang Nomor 33 Tahun 2014 Tentang Jaminan Produk Halal (2) Peraturan Pemerintah Nomor 31 Tahun 2019 Tentang Peraturan Pelaksana Undang-undang Nomor 33 Tahun 2014 Tentang Jaminan Produk Halal, dan (3) Peraturan Menteri Agama Nomor 26 Tahun 2019 Tentang Penyelenggara Jaminan Produk Halal. Sedangkan bahan hukum sekundernya adalah doktrin-doktrin, literatur hukum, jurnal, makalah, artikel, serta berbagai bahan bacaan lain yang berkaitan dengan permasalahan yang ada dalam penelitian ini.

\section{HASIL DAN PEMBAHASAN}

\section{Lembaga Sertifikasi Halal Di Indonesia}

Spesifikasi sertifikasi halal di indonesia terbatas pada bahan-bahan yang berasal dari hewan, tumbuhan, mikroba, dan bahan yang dihasilkan melalui proses kimiawi, proses biologi, atau proses rekayasa genetik dalam proses produksi pembuatan produk halal baik itu nantinya dijadikan sebagai bahan baku, bahan olahan, bahan tambahan, maupun bahan penolong harus halal menurut syariat agama. Jika bahan tersebut berasal dari hewan maka diharamkan cari ayat alquran (Vide pasal 17-22 UUJPH Jo. pasal 24 sampai dengan pasal 26 PMA 26/2019).

Spesifikasi bahan-bahan dan tata cara pengelolaan akan diproses oleh lembaga-lembaga 
yang berwenang antara lain:

\section{BPJPH}

BPJPH dibentuk berdasar Pasal 5 ayat (2) Undang-Undang Dasar Negara Republik Indonesia Tahun 1945, BPJPH setidaknya dibentuk untuk melaksanakan ketentuan Pasal 11, Pasal 16, Pasal 21 ayat (3), Pasal 44 ayat (3), Pasal 46 ayat (3), Pasal 47 ayat (4), Pasal 52, dan Pasal 67 ayat (3) Undang-Undang Nomor 33 Tahun 2014 tentang Jaminan Produk perlu menetapkan Peraturan Pemerintah tentang Peraturan Pelaksanaan Undang-Undang Nomor 33 Tahun 2014 tentang Jaminan Produk Halal.

Sesuai dengan amanat pasal 4 UUJPH, lalu Peraturan Presiden Nomor 83 Tahun 2015 Tentang Kementrian Agama Pasal 45 sampai dengan pasal 48 Tentang $\mathrm{BPJPH}$, dan terbitnya Peraturan Menteri Agama Nomor 42 Tahun 2016 yang memuat tentang struktur BPJPH, maka secara resmi berdirilah BPJPH.

BPJPH merupakan lembaga negara dibawah kementrian agama, Resmi di launching pada 11 Oktober 2017. BPJPH sebagai Lembaga Eselon 1/Dirjen , dipimpin oleh kepala badan JPH atau kepala BPJPH pada 02 Agustus 2017. Bertugas untuk mempersiapkan pelaksanaan atas amanat pasal 4 UUJPH, yakni produk yang masuk, beredar, dan diperdagangkan di wilayah Indonesia wajib bersertifikat halal karena untuk sebelumnya sertifikat halal adalah sukarela atau voluntary. BPJPH juga mempunyai tugas lainnya, yakni (1) Merumuskan dan menetapkan kebijakan JPH (2) Menetapkan norma, standar, prosedur, dan kriteria JPH (3) Menerbitkan dan mencabut Sertifikat Halal dan Label Halal pada Produk (4) Melakukan registrasi Sertifikat Halal pada produk luar negeri (5) Melakukan sosialisasi, edukasi, dan publikasi Produk Halal (6) Melakukan akreditasi terhadap LPH (7) Melakukan registrasi Auditor Halal (8) Melakukan pengawasan terhadap JPH (9) Melakukan pembinaan Auditor Halal; dan (10) Melakukan kerja sama dengan lembaga dalam dan luar negeri di bidang penyelenggaraan JPH (Vide Pasal 6 UU JPH). BPJPH menetapkan logo atau label yang diberlakukan di seluruh indonesia. Selain itu juga berwenang dalam penerbitan maupun pencabutan logo halal.

\section{LPH}

Mengacu pada Pasal 7 UU JPH, lembaga pemeriksa halal (LPH) adalah lembaga yang melakukan kegiatan pemeriksaan dan/atau pengujian terhadap kehalalan produk.

LPH dapat didirikan oleh pemerintah (pusat maupun daerah, kementrian/lembaga, didirikan oleh perguruan tinggi negeri (PTN), BUMN maupun BUMD) dan/atau masyarakat (diajukan oleh lembaga keagamaan islam berbadan hukum terbatas pada yayasan/perkumpulan saja) dengan keharusan memenuhi 4 syarat, yakni: (1) memiliki kantor sendiri dan segala perlengapannya; (2) memiliki akreditasi dari BPJPH; (3) memiliki auditor halal sedikitnya 3 (tiga) orang; (4) memiliki laboratorium/ kesepakatan kejasama dengan lembaga lain yang memiliki laboratorium.

Auditor mempunyai peran yang urgent, auditor halal diperlukan untuk memeriksa dan mengkaji bahan, proses pengolahan produk, sistem penyembelihan, meneliti lokasi produk, berbagai peralatan produksi, ruang produksi, penyimpanan, dan memeriksa pendistribusian dan penyajian produk. Itulah yang menjadikan sebab auditor halal harus berpendidikan minimal sarjana strata-1 bidang kimia/ biokimia/ biologi/ teknik industri/ farmasi dan yang terpenting ia harus mempunyai pengetahuan yang mumpuni tentang kehalalan menurut syariat islam.

Di Indonesia sendiri, baru terdapat dua perusahaan BUMN yang mendaftarkan diri sebagai LPH, yakni, PT. Surveyor Indonesia (SI) dan PT. Superintending Company of Indonesia atau Sucofindo (Pryanka, 2020).

\section{MUI}

Mulai proses terbitnya sertifikasi halal, peran MUI terlihat sangat penting. Hal ini tidak terlepas pula dari latar belakang berdirinya MUI di Indonesia. MUI yang lahir pada tanggal 17 Rajab $1395 \mathrm{H}$ atau bertepatan dengan tanggal 26 Juli 1975 M, di Balai Sidang Jakarta. Ia merupakan hasil dari Musyawarah Nasional (Munas) 1 yang telah berlangsung sejak tanggal 12 hingga 18 Rajab1395 $\mathrm{H}$ atau bertepatan dengan tanggal 2127 Juli 1975 M (Mudzhar, 1993). MUI atau Majelis Ulama Indonesia adalah Lembaga Swadaya Masyarakat yang mewadahi ulama, zu'ama, dan cendikiawan Islam di Indonesia untuk membimbing, membina dan mengayomi kaum muslimin di seluruh Indonesia.

MUI berdiri sebagai hasil dari pertemuan atau musyawarah para ulama, cendekiawan dan zu'ama yang datang dari berbagai penjuru tanah air, antara lain meliputi dua puluh enam orang ulama yang mewakili 26 Provinsi di Indonesia 
pada masa itu, 10 orang ulama yang merupakan unsur dari ormas-ormas Islam tingkat pusat, yaitu, NU, Muhammadiyah, Syarikat Islam, Perti. Al Washliyah, Math'laul Anwar, GUPPI, PTDI, DMI dan Al Ittihadiyyah, 4 orang ulama dari Dinas Rohani Islam, Angkatan Darat, Angkatan Udara, Angkatan Laut dan POLRI serta 13 orang tokoh/cendekiawan yang merupakan tokoh perorangan (MUI, 2018).

MUI dalam sistem ketatanegaraan bukan merupakan badan, lembaga, komisi negara yang atas dasar undang-undang, atau Pemerintah atas perintah undang-undang sebagaimana diatur dalam UU 12 Tahun 2011. Meskipun MUI disebutkan dalam beberapa Pasal UU Nomor 33 Tahun 2014 Tentang Jaminan Produk Halal, namun itu tidak berarti MUI dibentuk ataupun diperintahkan pembentukannya dengan undangundang ataupun peraturan daerah.

MUI sendiri berperan terhadap hasil pengujian yang disampaikan oleh Auditor kepada BPJPH karena nantinya akan diteruskan kepada MUI untuk ditetapkan status kehalalannya melalui Sidang Fatwa Halal (Pasal 32 UU JPH). Hasil keputusan mengenai produk diproses paling lama 30 (tiga puluh) hari kerja terhitung sejak hasil pemeriksaan diserahkan kepada MUI. Sidang ini tidak hanya dihadiri oleh anggota MUI, namun juga melibatkan pakar, instansi terkait, dan perwakilan kementerian atau kelembagaan. Keputusan dalam Sidang Fatwa Halal ditandatangani MUI kemudian diserahkan kepada BPJPH untuk bisa dikeluarkan sertifikat halal (Pasal 33 UU JPH).

\section{Kerjasama Pelaksanaan Jaminan Produk Halal}

Berdasar pasal 7 UUJPH yang menyatakan bahwa dalam melaksanakan jaminan produk halal, Badan Penyelenggara Jaminan Produk Halal/ BPJPH mempunyai kewenangan bekerjasama dengan: (a) Kementerian dan/atau lembaga terkait, (b) Lembaga Pemeriksa Halal, dan (c) Majelis Ulama Indonesia. Hal tersebut selaras dengan bunyi pasal 4 ayat (4) PP 31/2019.

Bentuk kerjasama antara BPJPH dengan kementerian terkait harus sesuai dengan tugas dan fungsi tiap-tiap kementerian. Jika mengacu pada pasal 5 ayat (2) PP 31/2019 setidaknya terdapat 6 kementrian yang dapat membantu pelaksanaan jaminan produk halal di Indonesia, diantaranya ada kementerian perindustrian, perdagangan, kesehatan, pertanian, koperasi dan usaha kecil dan menengah, dan kementrian luar negeri.
Dalam pasal tersebut pula tidak menutup kemungkinan untuk kementerian lain dapat menjadi penyelenggara JPH. Kesemua bentuk kerjasama kementerian dalam menyelenggarakan urusan pemerintahan dijelaskan dalam pasal 6 sampai dengan pasal 12 PP 31/2019.

Ketentuan mengenai tata cara kerja sama sebagaimana dimaksud dalam PP 31/2019 disebutkan secara rinci dalam Peraturan Menteri Agama RI No. 26/2019 Tentang Penyelenggaraan JPH mulai dari pasal 4 ayat (2), pasal 6 sampai dengan pasal 12. Salah satunya bentuk kerjasama atau koordinasi antara BPJPH dengan kementerian perindustrian ialah dalam ruang lingkup pengaturan, pembinaan dan pengawasan industri untuk mengahasilkan produk halal, pembentukan kawasan industri halal, sebagai penyedia fasilitas halal bagi industri kecil dan menengah.

Atau bentuk kerja sama BPJPH dengan kementerian kesehatan misalnya dalam hal penetapan cara produksi serta cara distribusi obat, termasuk vaksin, obat tradisional, kosmetik, alat kesehatan, perbekalan kesehatan rumah tangga, makanan, dan minuman.

Dalam pasal 6 sampai dengan pasal 12 PMA khususnya ayat (2) Peraturan Menteri Agama RI No. 26 Tahun 2019 terdapat ketentuan yang berbunyi "Perumusan dan penetapan kebijakan kerja sama dengan ruang lingkup sebagaimana dimaksud pada ayat (1) berkoordinasi dengan BPJPH." Koordinasi antara BPJPH dengan kementrian tersebut dimaksudkan agar terjadi sinergisitas antar keduanya, tidak terjadinya tumpang tindih kewenangan antara kementerian dan lembaga terkait dengan BPJP berkaitan dengan penyelenggaran jaminan produk halal.

\section{Prosedur Sertifikasi Halal Di Indonesia}

Setelah dikeluarkannya peraturan pelaksana, prosedur pengajuan sertifikasi halal dilaksanakan oleh BPJPH melalui enam tahapan, yakni: (1) Pengajuan permohonan secara tertulis oleh pelaku usaha (Vide pasal 29 UUJPH Jo. Pasal 91-99 PMA 26/2019 Tentang Penyelenggara JPH); (2) Pemeriksaan kelengkapan dokumen permohonan (pasal 100 dan pasal 101 PMA 26/2019); (3) Penetapan LPH, LPH tersebut harus memperoleh akreditasi dari BPJH yang bekerjasama dengan MUI (Vide pasal 102 PMA 26/2019); (4) Pemeriksaan dan pengujian produk oleh auditor halal (Vide pasal 31-32 UUJPH Jo. Pasal 103-112 PMA 26/2019); (5) Penetapan kehalalan produk 
oleh MUI dalam sidang fatwa halal (Vide pasal 33 UUJPH Jo. Pasal 113-117 PMA 26/2019); (6) Penerbitan sertifikasi halal (Vide pasal 34-36 UUJPH).

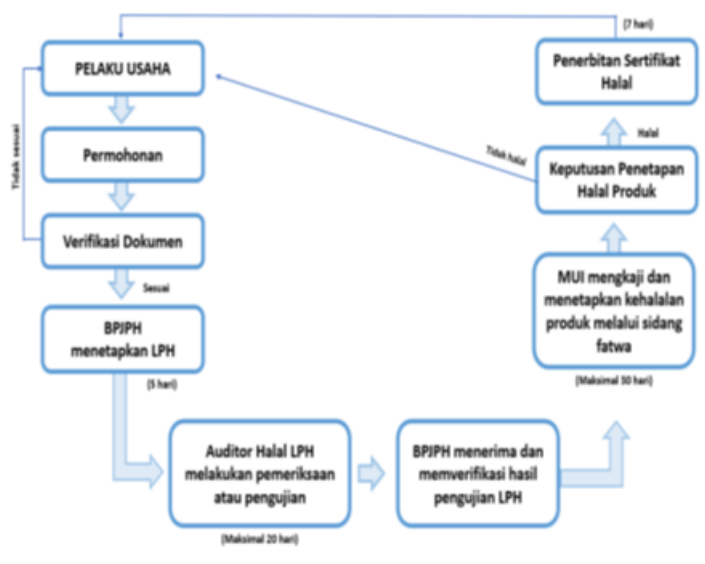

Gambar 1

Mekanisme sertifikasi oleh BPJPH (Faridah, 2020)

Para pelaku usaha juga berkewajiban untuk memperbaharui/memperpanjang sertifikat halal jika masa berlakunya telah berakhir (Vide pasal 25 huruf d UUJPH). Sertifikat halal sendiri berlaku selama kurun waktu 4 tahun, pelaku usaha harus mengajukan permohonan pembaharuan paling lambat 3 bulan sebelum masa sertifikat berakhir. (Vide pasal $42 \mathrm{UUJPH}$ Jo. Pasal 120 PMA 26/2019). Pelaku usaha harus memberikan jaminan halal dengan selalu menjaga konsistensi kehalalan produk. Secara berkala setiap enam bulan sekali harus melaporkan pelaksanaan Sistem Jaminan Halal (SJH) pada perusahaannya. Adapun mekasnisme pembaharuan sertifikat halal berdasar PMA 26/2019 ialah:

Pelaku usaha mengajukan permohonan tertulis dalam bahasa Indonesia kepada BPJPH.

BPJPH melakukan pemeriksaan kelengkapan dokumen (salinan sertifikat halal dan surat pernyataan yang menerangkan Produk yang didaftarkan tidak mengalami perubahan dengan dibubuhi materai sesuai dengan ketentuan peraturan perundang-undangan).

Penetapan LPH untuk pemeriksaan dan/atau pengujian kehalalalan produk ulang, jika terdapat perubahan komposisi bahan, pelaku usaha harus melaporkan dokumen perubahannya dan salinan sertifikat halal atas bahan mana saja yang dirubah. Apabila perubahan pada bahan tidak didukung oleh laporan, maka pelaku usaha harus mengajukan permohonan pembaharuan ulang kepada BPJPH. (Vide pasal 121-123 PMA 26/2019).

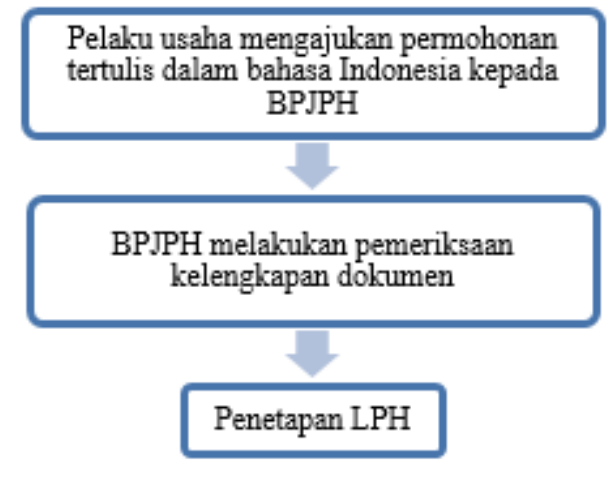

Gambar 2

Mekanisme pembaharuan sertifikasi oleh BPJPH

Biaya sertifikasi halal terdiri atas; biaya pengajuan permohonan sertifikat halal, biaya pemeriksa dan/atau pengujian kehalalan produk, biaya pengkajian ilmiah terhadap hasil pemeriksa dan/atau pengujian kehalalan produk, biaya pelaksanaan sidang fatwa halal, dan biaya penerbitan sertifikat.

Kesemua biaya dibebankan kepada para pelaku usaha yang mengajukan permohonan sertifikat halal. Namun dalam rangka memperlancar pelaksanaan penyelenggaraan JPH, UU 33/2014 memberikan peran bagi pihak lain seperti Pemerintah melalui anggaran pendapatan dan belanja negara, pemerintah daerah melalui anggaran pendapatan dan belanja daerah, perusahaan, lembaga sosial, lembaga keagamaan, asosiasi, dan komunitas untuk memfasilitasi biaya sertifikasi halal bagi pelaku usaha mikro dan kecil.

\section{Labelisasi Halal}

Pasal 1 angka 11 UUJPH menyebutkan, label halal adalah tanda kehalalan suatu produk. Tujuan adanya pencantuman label atau tanda halal yang khas dalam kemasan produk-produk halal ialah untuk menunjukkan dan memberi kepastian kepada konsumen khususnya konsumen muslim, bahwa produk tersebut merupakan produk yang berstatus halal berdasar serangkaian pemeriksaan oleh BPJPH, LPH, dan Auditor, untuk kemudian ditetapkan status kehalalannya melalui sidang fatwa MUI dalam bentuk sertifikat halal.

Sedangkan untuk sertifikat halal sendiri adalah pengakuan kehalalan suatu produk yang dikeluarkan oleh BPJPH berdasarkan fatwa halal 
tertulis yang dikeluarkan oleh MUI. Sertifikat halal yang dikeluarkan oleh MUI itulah yang menjadi dasar para pelaku usaha dapat mencantumkan label halal pada produknya.

Label halal apa yang dipakai? mengacu pada Peraturan Pemerintah Republik Indonesia Nomor 69 Tahun 1999 tentang Label dan Iklan pangan, menerangkan bahwa pemasangan Label Halal pada kemasan yang harus melalui pemeriksaan terlebih dahulu oleh lembaga pemeriksa yang terakreditasi berdasarkan pedoman dan tata cara yang ditetapkan Menteri Agama (Afroniyati, 2017). Keputusan Menteri Agama (KMA) 518 Tahun 2001 dan KMA 519 Tahun 2001 menerangkan bahwa Menteri Agama menunjuk MUI sebagai lembaga sertifikasi halal yang melakukan pemeriksaan, pemrosesan, dan penetapan Sertifikasi Halal. Sedangkan mengenai pemasangan logo halal pada kemasan, MUI bekerjasama dengan BPOM.

Produk yang masuk, beredar, dan diperdagangkan di Indonesia, wajib untuk bersertifikasi halal (Vide pasal 4 UUJPH). Jenis produk yang wajib untuk bersertifikat halal diklasifikasikan menjadi 2 hal, yakni barang dan jasa. Untuk barang, ada makanan, minuman, obat, kosmetik, produk kimiawi, produk biologis, produk rekayasa genetik, dan barang gunaan yang dipakai, digunakan, dan dimanfaatkan. Batasannya untuk kewajiban sertifikasi pada barang gunaan ialah untuk produk sandang hanya sebatas (pakaian, kaos kaki, dan jaket yang berasal dari hewan), penutup kepala (peci, kerudung, dan helm yang mengandung komposisi hewan), aksesoris (cincin, jam tangam, dompet, dan kacamata yang mengandung komposisi hewan), perbekalan rumah tangga (sikat gigi, tusuk gigi, sendok, pisau, piring), perlengkapan peribadatan umat islam (sajadah, sarung, mukena), kemasan makanan dan minuman (plastik, sterofoam), alat tulis dan perlengkapan kantor (tinta, lem, dan kertas pembuatan alquran), dan yang terakhir alat-alat kesehatan (katup jantung, benang bedah, gigi palsu). (Vide pasal 68 dan pasal 71 PP 31/2019 Jo. Pasal 28-29 PMA 26/2019).

Sedangkan untuk jasa, meliputi layanan usaha dalam proses/ hal penyembelihan, pengelolaan, penyimpanan, pengemasan, pendistribusian, penjulan, dan jasa penyajian.

Berikut adalah label halal Indonesia yang dipakai untuk produk-produk bersertifikasi halal, sebagai perbandingan penulis akan menampilkan pula label halal dari negara-negara tetangga.

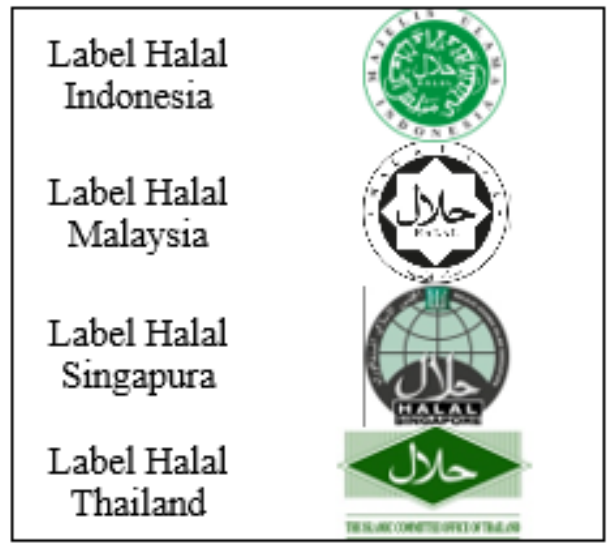

Gambar 3

Label Halal Indonesia, Malaysia, Singapura, dan Thailand

Produk yang berasal dari bahan yang diharamkan dikecualikan dari kewajiban bersertifikat halal. Untuk produk pengecualian, boleh tidak mendafatran sertifikasi halal, tetapi dalam produknya harus mencantumkan label tidak halal. Produk yang berasal dari bahan yang diharamkan tidak memiliki kewajiban bersertifikat halal, tetapi berkewajiban memberi keterangan tidak halal pada produknya (Vide $\mathrm{Pa}$ sal 2 PPJPH Jo. Pasal 27 PMA No.26/2019).

Sertifikasi halal merupakan etika bisnis yang seharusnya dijalankan produsen sebagai jaminan halal bagi konsumen. Selain sebagai jaminan halal terhadap konsumen, label halal memberikan keuntungan ekonomis bagi produsen diantaranya: (a) dapat meningkatkan kepercayaan konsumen karena terjamin kehalalannya, (b) Memiliki USP (Unique Selling Point), (c) Mampu menembus global halal market, (d) Meningkatkan marketability produk di pasar, (e) Investasi yang murah jika dibandingkan dengan pertumbuhan revenue yang dapat dicapai (Nahrowi \& Rahman, 2014).

\section{Pemberlakuan Sertifikasi Halal}

Kewajiban sertifikasi halal sesuai dengan UU JPH diberlakukan mulai pada tanggal 17 Oktober 2019 sampai dengan tanggal 17 Oktober 2024. Pelaksanaannya dilakukan secara bertahap dengan mempertimbangkan kesiapan pelaku usaha, kesiapan infrastruktur pelaksanaan JPH, melihat jenis Produk sebagai kebutuhan primer dan dikonsumsi secara masif yang memiliki titik kritis ketidakhalalan yang tinggi.

Kewajiban produk bersertifikasi halal bertahap dimulai dari produk makanan dan minuman, baru 
selanjutnya untuk produk-produk obat-obatan, kosmetik, barang gunaan, dan alat-alat kesehatan. (Vide pasal 31-35 PMA 26/2019). Setelah 17 Oktober 2024, semua produk yang beredar dan diperdagangkan diwilayah Indonesia wajib bersertifkat halal (Vide pasal 67 UU JPH). Selama kurun waktu lima tahun ini, BPJPH akan lebih persuasive dalam melakukan sosialisasi dan pembinaan kepada pelaku usaha. Memberi kesempatan kepada pelaku usaha untuk mengurus sertifikasi halal. Produk yang belum memiliki sertifikasi halal tidak langsung dijatuhkan hukuman, namun tetap diberi kesempatan untuk mengurus sertifikasi halal sampai 17 Oktober 2024.

Dalam menegakkan kewajiban penerapan sertifikasi halal, UU JPH telah menjamin dengan cara mengatur ketentuan pidana, baik itu sanksi pidana penjara maupun sanksi administratif/ sanksi denda terhadap para pelaku usaha yang tidak mematuhi, menjamin penegakan hukum UU $\mathrm{JPH}$, dan tidak menjaga kehalal produk yang telah memperoleh sertifikat halal.

\section{SIMPULAN}

Dibentuknya Undang-Undang Nomor 33 Tahun 2014 Tentang Jaminan Produk Halal, Peraturan Pemerintah Nomor 31 Tahun 2019, dan Peraturan Menteri Agama Nomor 26 Tahun 2019 Tentang Penyelenggara Jaminan Produk Halal semakin memperjelas bahwa betapa mendesaknya permasalahan halal dan haram di Indonesia. peraturan tersebut menunjukkan bahwa terdapat tiga lembaga urgent yang berwewenang menjalankan sertifikasi halal di Indonesia, yakni ada BPJPH, LPH, dan MUI. BPJPH mempunyai kewenangan untuk bekerjasama salah satunya dengan Kementerian dan/atau lembaga terkait, bentuk kerjasamanya harus sesuai dengan tugas dan fungsi tiap-tiap kementerian.

Prosedur pengajuan sertifikasi halal dilaksanakan melalui enam tahapan, yakni: mulai dari (1) Pengajuan permohonan secara tertulis oleh pelaku usaha; (2) Pemeriksaan kelengkapan dokumen permohonan; (3) Penetapan LPH, LPH tersebut harus memperoleh akreditasi dari BPJH yang bekerjasama dengan MUI; (4) Pemeriksaan dan pengujian produk oleh auditor halal; (5) Penetapan kehalalan produk oleh MUI dalam sidang fatwa halal; dan terakhir (6) Penerbitan sertifikasi halal. Selanjutnya para pelaku usaha berkewajiban untuk memperbaharui sertifikat halal jika masa berlakunya telah berakhir (4 tahun). pengajuan permohonan pembaharuan paling lambat 3 bulan sebelum masa sertifikat berakhir.

Kewajiban sertifikasi halal sesuai dengan UUJPH diberlakukan mulai pada tanggal 17 Oktober 2019 sampai dengan tanggal 17 Oktober 2024. Pelaksanaannya dilakukan secara bertahap dengan mempertimbangkan kesiapan pelaku usaha, kesiapan infrastruktur pelaksanaan Jaminan Produk Halal, dan mempertimbangkan jenis Produk sebagai kebutuhan primer dan dikonsumsi secara masif.

\section{DAFTAR PUSTAKA}

A.S, H. (1999). Islam Demokrasi dan Pemberdayaan Civil Society. Jakarta: Erlangga.

Afroniyati, L. (2017). Analisis Ekonomi Politik Sertifikat Halal oleh MUI. Jurnal Kebijakan dan Administrasi Publik , 18(1): 37-52. Retrieved from https://doi.org/10.22146/ jkap. 6870

Endah, N. H. (2014). Perilaku Pemberian Kosmetik Berlabel Halal Oleh Konsumen Indonesia. Jurnal Ekonomi dan Pembangunan , Vol. 22 No. 1, p. 12. Retrieved from https:// doi.org/10.14203/JEP.22.1.2014.25-39

Faridah, H. D. (2020). Halal Certification In Indonesia : History, Development, And Implementation. Universitas A irlangga: Journal of Halal Product and Research, Retrieved fromhttp://dx.doi.org/10.20473/jhpr.vol.2issue. 2.68-78

Hasan, K. S. (2014). Kepastian Hukum Sertifikasi dan Labelisasi Halal Produk Pangan. Jurnal Dinamika Hukum .14(2), 235. Retrieved from http://dx.doi.org/10.20884/1.jdh.2014.14.2.292

Ilyas, M. (2017). Certification and Labeling Halal Products of Maslahat Perspective. Jurnal AlQadau , 357-367. Retrieved from http:// journal.uin-alauddin.ac.id/index.php/al-qadau/ article/view/5682

Kusnandar, V. B. (2019). Indonesia Negara dengan Penduduk Muslim Terbesar Dunia. Indonesia: https://databoks.katadata.co.id/.

Marzuki, P. M. (2001). Penelitian Hukum. Yuridika. 16(2).

Marzuki, P. M. (2016). Penelitian Hukum Edisi Revisi. Jakarta: Kencana Prenada Media Group.

Mudzhar, M. A. (1993). Fatwa-Fatwa Majelis Ulama Indonesia: Sebuah Studi Pemikiran Tentang Hukum Islam di Indonesia. Jakarta: INIS.

MUI. (2018). Kepengurusan Dewan Pimpinan MUI. Indonesia: https://mui.or.id/kepengurusan/.

Nahrowi, N., \& Rahman. R. (2014). Sertifikasi Halal sebagai Penerapan Etika Bisnis dalam Upaya Perlindungan bagi Konsumen Muslim. A hkam, 14(1), 145-154. Retrieved from http:// 
dx.doi.org/10.15408/ajis.v14i1.1251

Pryanka, A. (2020). BPJPH: Lembaga LPH. Indonesia: Khazanah Republika.

RFQ. (2014). UU Jaminan Produk Halal Berikan Kepastian Hukum Bagi Konsumen. Retrieved from http://www.hukumonline.com/berita/baca/ lt54241d9c5a5ed/uu-jaminan-produkhalalberikan-kepastian-hukumbagi-konsumen.

Statistik, B. P. (2010). Sensus Penduduk 2010: Penduduk Menurut Kelompok Umur dan Agama yang Dianut. Indonesia: https:// sp2010.bps.go.id. 